\title{
Larysa LEVCHENKO
}

Doctor of Historical Sciences (Dr. Hab. in History), Professor,

Senior Research Fellow,

Institute of Ukrainian Archaeography and Source Studies

named after M.S.Hrushevskyi NAS of Ukraine;

Director at Central State Archives

of Supreme Bodies of Power and Government of Ukraine

(Kyiv, Ukraine), loralewch@gmail.com

ORCID: https://orcid.org/oooo-oooI-9097-7373

\section{Greek Churches in the Southern Ukraine in the Making (the Late Eighteenth - the First Half of the Nineteenth Century)}

\author{
DOI: https://doi.org/10.15407/!!!! \\ UDC: $271.222(495+477.7) \ll 17 / 18 \gg$
}

\begin{abstract}
The purpose of the article is to present the results of the study on the history of Kherson and Mykolaiv Greek churches at the end of the 18th and the first half of the 19th cent. The research methodology is based on the generally accepted principles and methods of historical study. Scientific novelty. The history of Greek churches in Kherson and Mykolaiv is covered based on handwritten sources from the state archives of Kherson, Mykolaiv, and Odesa regions. This data is introduced into the scientific body of knowledge for the first time. These sources provided an opportunity to study new facts and names, made conclusions on the role of the Church in the life of Kherson and Mykolaiv Greek communities. Conclusions. The history of the Greek churches reflects the history of the Greeks in the Southern Ukraine under the dominion of the Russian Empire. When the Greeks settled in Kherson, their ties with their country of origin were quite strong. It is clear in the decor of the St. Sophia's Greek Church, in the wishes to have the priests serving in Greek. The Russian government tended to take the Greek citizens under control with the help of the Russian Orthodox Church. The Greek priests obeyed the regulations of the Russian Church. By the time when the Greeks reached Mykolaiv, their ties with their native land had become weaker. The Greeks serving in the Black Sea Navy were hardly interested in the St. Nicholas Greek Church construction because the Admiralty Cathedral satisfied their religious needs. These Greeks were subjected to assimilation faster than their compatriots not serving in the Navy. The Mykolaiv community of civil Greeks was insolvent and could not build their Church without government aid and the donations of other nationalities' representatives. The lack of budget instigated a search for funds, disputes on moneyrelated issues, and mutual recriminations of fraud. The assimilation of the civil Greeks manifested in the architecture of the Mykolaiv Greek Church, built as a smaller copy of the Admiralty Cathedral, in the Russian names of the Greeks who were parishioners of the Greek Church, and in the control that the Russian priests had over it. The history of Kherson and Mykolaiv Greek churches is different from the history of the Odesa Holy Trinity Church that became a shelter for participants of the movement for Greek statehood. The Greek churches not only helped the Greeks integrate into a foreign environment and preserve national culture but also promoted their assimilation.
\end{abstract}

Keywords: Greek churches in the Southern Ukraine, Church of St. Sophia in Kherson, Church of St. Nicholas in Mykolaiv, Greeks in Ukraine, Greeks in the South of the Russian Empire.

The Orthodox Churches in the Southern Ukraine (or the Northern Black Sea region), founded and built by the Greeks who had migrated there at the end of the eighteenth - at the beginning of the nineteenth century, were the centres of the Greeks' 
consolidation both in a spiritual sense and in the national and cultural dimensions. Yet, the Greeks have never been an isolated group in Ukraine. They fully integrated into the local multi-ethnic orthodox populace. Therefore, the Greek churches have never been solely Greek. Their parishes have united with the ones of Orthodox Christians of different nationalities. Moreover, metrical books of the Greek churches demonstrate some ethnic contacts and ethnically mixed marriages between the Greeks, the Ukrainians, the Russians and the believers from other orthodoxy nations. As a result of these processes, in the Independence of Ukraine period, the representatives of different nations are interested in saving and renovating such monuments of culture as Greek churches as well as in researching the history of these churches, their parishes, and priests' biographies.

The modern historiography on the chosen topic contains the writings of secular and ecclesiastic historians dedicated to the history of the Church, church architecture, and scientific works on the history of the Greeks of Ukraine. Concerning the contemporary historiography of the Church history, I. Lyman highlights that it is currently in a phase of 'ecclesiastical renaissance' which followed after compulsory atheism of the Soviet times. The term 'renaissance' can be applied both to the historiography of the church architecture and national minorities.

Historiographical analysis shows that the history of the Holy Trinity Greek Church and the Greek community of Odesa was studied thoroughly ${ }^{2}$. The reason is that Odesa was a center of the Greek national movement where the organization 'Filiki Eteria' (or Society of Friends) was founded'. It is known that the first meetings of 'Filiki Eteria' were held in the Holy Trinity Greek Church. The histories of the Greek churches of St. Sophia (Kherson) and St. Nicholas (Mykolaiv) have not found their researchers yet, so they are still immersed in myths and legends. Therefore, the submitted research addresses the history of creating the Greek churches of Kherson and Mykolaiv, the erection of buildings, and the beginnings of their functioning. On this matter, V.Tomozov's conclusions are the most interesting because they concern the same period and territory but another category of people - the richest and the most famous Greek dynasties. He observed similar tendencies among them which will be demonstrated in this articlet.

Previously unknown primary sources for this study were discovered in the state archives of Kherson (Kherson Spiritual Board of the Kherson Spiritual Consistory, F.207), Mykolaiv (Mykolaiv Admiralty Cathedral of the Archpriest of the Military and Naval Clergy, F.I68), and Odesa (Kherson Spiritual Consistory, F.37) regions. These documents were not entered into the scientific body of knowledge due to illegible handwritten texts. They provided an opportunity to study new facts and names, made conclusions on the role of the Church in the life of Kherson and Mykolaiv Greek communities.

The generally accepted principles (objectivity, impartiality, comprehensiveness) and methods (chronological, comparative, alternative, archival heuristics) of historical science were used in the processing of empirical data.

\footnotetext{
Лъман И.И. История церкви в Украине: специфика современной историографической ситуации // Религиозные традиции Европы и современность: изучение и преподавание в российских и зарубежных университетах / Под ред. Д.И.Полывянного. - Иваново, 2011. - С.190-198.

2 Греки Одессы: Именной указатель по метрическим книгам одесской Греческой Свято-Троицкой церкви / Белоусова Л.Г. и др. - Ч.1: 1800-1831. - Одесса, 2000. - 364 с.; Ч.2: 1834-1852. - Одесса, 2002. - 372 с.; Ч.3: 1853 1874. - Одесса, 2004. - 237 с.; Ч.4: 1875-1891. - Одесса, 2004. - 332 с.; Ч.5: 1802, 1892-1906. - Одесса, 2005. - 242 с.; Ч.6: 1907-1920. - Одесса, 2009. - 344 с.; Ч.І: 1799-1831, 1836 (изд. 2-е, доп.). - Одесса, 2014. - 552 с.

3 Терентьєва Н.О. Таємне грецьке товариство «Філікі Етерія»: Організаційний та політико-ідеологічний центр підготовки грецької революції 1821-1829 рр. - К., 2005. - 352 с.; Їі ж. Греки в Україні: історія та сучасність. К., 2008. - Ч.1. - 350 с.; Ч.2. - 318 с.

${ }_{4}$ Томозов В.В. Греки-хіосці на Півдні України (кінець XVIII ст. - 1917 р.): між традиціями національного самозбереження і практиками соціокультурної адаптації / Відп. ред. Г.В.Боряк. - К., 2020. - 354 с.
} 


\section{The Historical Background of Greek Migration to the Northern Black Sea Coast}

It is important to consider the historical background of Greek migration to the Northern Black Sea coast. In the middle of the seventh century B.C., Ancient Greeks founded city-states in the Northern Black Sea area, so their descendants had to be well acquainted with its advantages. During the years 395-I435, the Greeks were the principal national group in the Christian Byzantine Empire, and after its fall, they found themselves under the power of the Muslim Turks throughout the territory of the Ottoman Empire. In I492, Metropolitan of Moscow Zosima put forward the idea of 'Third Rome', according to which Russians claimed leadership in the Orthodox world. Although this theory came into being on religious grounds, it had a significant impact on the development of the 'Eastern Question'. In 1768, the Ottoman Empire declared war on Russia, and the Russian government supported an uprising of the Greeks against Turkish dominance. In the war, Russia sought to seize the Northern Black Sea region and only then liberate the Orthodox peoples from the Ottoman yokes. The first Archipelago expedition of the Russian Imperial Navy (I768-I774) was an integral part of the so-called 'Greek Project' of Empress Catherine the Great. The Kuchuk-Kainarji Treaty signed on July Io, I774, stated that 'the Russian Empire gives back to the Sublime Porte all Archipelago islands which depended on the Ottomans' previously. The Greeks who participated in the rebellion and entered the crews of the Russian Navy had to abandon their houses. In I775, the ships of the Russian Navy transported Greek families from the Archipelago to Crimea. The situation in Crimea was uncertain: according to the Treaty, the Crimean Khanate became independent both from the Ottoman Porte and the Russian Empire. However, the Russian government pursued to undermine the economy of the Khanate with the aim of speedy annexation. In $1778-1780$, the native Greek inhabitants of the Khanate were forcibly moved from the Crimean Peninsula to the Azov. The Greeks from the Archipelago migrated to the Northern Black Sea area. These migrations resulted from the policies of Empress Catherine the Great directed towards the annexation of Crimea.

V.Timofeenko wrote that in $178 \mathrm{I}, \mathrm{I783}$, and 1787 the tsarist government had issued the Decrees to settle the Northern Black Sea area. As a result, already in $1782,4,32 \%$ of the total population in the region were Greek. According to V.Timofeenko, the Greeks first settled in the Ochakiv region ${ }^{6}$.

Indeed, one of the first Greek churches built from wooden materials appeared in Ochakiv at that time. It was erected by parishioners with the permission of Ambrosius, Metropolitan of Katerynoslav, Tavria, and Kherson. On November 9, 1792, protopope Bogdanovich consecrated the Church in honour of St. Nicholas ${ }^{7}$. This Church was mentioned for the last time in the records of the Kherson Theological Board in $1807^{8}$. A.Pyvovar believes that the worship in this Church did not begin due to the small number of parishioners?.

According to the Decree 'On the benefits of Greek and Bulgarian emigrants emerging from the Novorossiysk province’ issued by Emperor Alexander the First on January 5, I802, the Chief of the Novorossiysk Patronage Office Samuel Kontenius had to provide

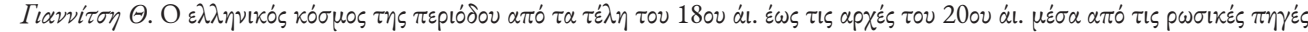

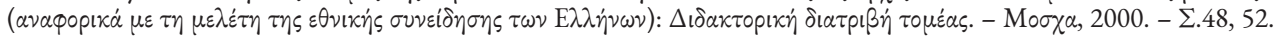

6 Тимофеенко В. Города Северного Причерноморья во второй половине XVIII в. - К., 1984. - С.21-22.

Пивовар A.B. До питання про церковне будівництво на території краю в другій половині XVIII - першій третині XIX ст. (Херсонщина і правобережна Катеринославщина) // Інгульський степ. - Вип.3. - К., 2018. - С.128.

8 Державний архів Одеської обл. (далі - ДАОО). - Ф.37. - Оп.2а. - Спр 61.

? Пивовар А. В. До питання про церковне будівництво... - С.143.
} 
the Greek immigrants with loans for starting farms and building houses in the national style. In reality, the tsarist government's policy was not as favourable as it may have seemed at first sight. The poor migrants lost an opportunity to return to their homeland because they were not able to pay back loans to the Russian government. Yet, by the time this Decree was issued, enough large Greek communities had already formed in the cities of the Northern Black Sea area - Kherson, Mykolaiv, and Odesa.

\section{Establishing the Greek Church in the Kherson City}

The city of Kherson was founded in 1778 as a fortress, shipyard, and city-port, where the Black Sea Navy of the Russian Empire was quartered at the end of the eighteenth century. At that time, Empress Catherine the Great paid attention to Kherson as a central place in the 'Greek Project' ${ }^{\text {Io }}$. On June 16, I780, the Black Sea Navy Commander-in-Chief Ivan Gannibal approved the founding of St. Sophia Church in the merchant (Greek) suburb - 'the Vorstadt'. The church was consecrated on November Io of the same year. It was constructed out of clay and wood.

The original iconostasis made of walnut wood is still extant. It was transported from Chios by the Gounaropoulos family of priests. The age of the iconostasis is estimated to exceed 450 years. It was hand-carved by Greek masters. Its five tiers contain 104 icons. Some icons have been upgraded or replaced, but several originals from Chios are still kept in the St. Sophia Church. Moreover, brothers Athanasiy, Stephan, and Dmitriy and their father Mikhail Gounaropoulos removed the wooden sculptures of four Evangelical Apostles from the Chios Church bell tower. These objects still adorn the bell tower of the St. Sophia's Church in Kherson. The Gounaropoulos also moved all ritual implements of the Chios Church to Kherson. Some family members are buried near the Kherson Greek Church of St. Sophia.

On November I0, 1780, Archbishop of Sloviansk and Kherson Nikephoros Theotokis consecrated the Church of St. Sophia ${ }^{\text {II }}$ and appointed the first Greek priest Joachim Papachristo. Nikephoros Theotokis was an influential figure of that time. His influence prompted Metropolitan of Moscow Platon the Second to permit the rite of monotheism services in Greek churches ('Orthodox Old Believers'). In 1782, Nikephoros Theotokis arrived in Kherson to take back his liturgical garments, but Papachristo had already took possession of these items. It was discovered that Joachim Papachristo had been forbidden to serve in the church since $178 \mathrm{r}$ : he was sent to Taganrog due to 'his dishonest life and bad deeds'. Despite the ban, he continued to serve in Taganrog. Finally, in 1786 , Joachim Papachristo was stripped of his priesthood and expelled from Kherson for misconduct ${ }^{12}$.

Between 1784 and 1786, the Greek hieromonk Jeremiah Grammatikopoulo served in the church. After he left Kherson for Constantinople, the Church needed a priest who could speak Greek ${ }^{13}$. At the time, Archbishop of Sloviansk and Kherson Eugene Bulgaris, a Greek by birth, was the rector and patron of schools in the Patriarchate of Constantinople. S.Makarov suggested he could serve in the church in $1784-1787$, though he required confirmation since his cathedra was situated in Poltava ${ }^{14}$.

\footnotetext{
${ }_{10}^{10}$ Кухар-Онышко Н.А. Жизнь и смерть светлейшего князя Потёмкина Григория Александровича. - Николаев, 2002. - С.42.

${ }_{11}$ Державний архів Херсонської обл. (далі - ДАХО). - Ф.207. - Оп.1. - Спр.62. - Арк.4, 19.

12 Там само. - Спр.75. - Арк.1.

${ }_{13}$ Там само. - Спр.99. - Арк.1.

${ }_{14}$ Макаров С. Греки Херсона // Херсонский вестник. - 2012. - №8 (1122). - С.17.
} 
The search for a Greek priest was complicated by the Decree of Catherine the Great dated December 7, 1785 , prohibiting the admission of Greek clergy to the Russian Empire, except for those who had the relevant letters of the Constantinople Patriarch and the passports issued by the Russian consulate in Constantinople.

The Russian establishment assumed Greek clergymen returning to their homeland spread false rumours about the Russian Empire ${ }^{15}$. Any Greek clergymen, including bishops, were to be detained in the border provinces for examination and verification of documents $^{16}$. In March 1786 , Kherson archpriest Ioann Bogdanovich received a Decree on the supervision of 'wandering priests' and a ban on their admission to church service. The Greek community asked the Archbishop of Katerynoslav, Chersonesus, and Tavria Ambrosius to allow a pro-hegumen Agafangel of Kefalonia to serve in the church or to invite another worthy priest from Greece. Agafangel came to Kherson in December 1786 to his brother who was not in the city. Agafangel could not return to his motherland due to the weather ${ }^{17}$. He did not provide documentary evidence of his priesthood, so he did not receive permission to serve ${ }^{18}$.

To solve the problem, in $\mathbf{1 7 8 6}$, by the Decree of Catherine the Great, Athanasius Langerov (Lengarov) was appointed the priest of the Kherson Greek Church since he spoke both Greek and Russian ${ }^{19}$. In I79I, deacon Manuel Stefanov as well as hieromonks Benjamin and Bartholomew, who somehow found themselves in Jassy, were also sent to Kherson $^{20}$.

Such topic as staffing the Black Sea Navy with hieromonks and the institute of naval priests established in the Russian Empire by the Decree of Peter the Great in I7I9 are quite interesting but exceed the chosen subject matter of this article. In 1793, a Decree was issued to send 43 hieromonks to the Black Sea Navy under the command of Rear Admiral M.Mordvinov ( 30 people probably were sent from the capital, and 13 were selected in the Katerynoslav province). These monks obtained the status of priests and served on ships. Some of them were seconded to the Kherson Greek Church ${ }^{21}$, but their names do not appear in archival documents.

In 1793, Hieromonk Benjamin illegally conducted six wedding ceremonies for people who did not belong to his parish and came under investigation ${ }^{22}$. In the same year, it became known that he kept relics that he had received in Jassy from the late Metropolitan of Katerynoslav and Tavria Gabriel (Bonulesco-Bodoni), a Greek by birth. According to Gabriel's will, Benjamin was to deliver these relics to the Sviatohorskyi monastery. Instead, together with hieromonk Spiridon, he used the relics to perform paid rituals for the Greek settlers of Kherson. After the investigation that followed, the relics were confiscated and Benjamin was expelled from the Russian Empire in the spring of $1794^{23}$.

The archpriest of the Kherson Merchant and Greek churches Fedor Sharynsky could not serve in both churches and sit on the Kherson Spiritual Board at the same time ${ }^{24}$. Therefore, hieromonk Jeremiah Grammatikopoulo returned from Constantinople and became the priest of the Kherson Greek Church in accordance with the Imperial Decree

\footnotetext{
${ }^{15}$ Полное собрание законов Российской империи. - Собрание первое (1649-1825). - Т.22. - Санкт-Петербург, 1830. №16294. - С.495-497.

${ }_{16}$ ДАХО. - Ф.207. - Оп.1. - Спр.68. - Арк.1-7.

${ }_{17}$ Там само. - Спр.93. - Арк.1, 4.

${ }_{18}$ Там само. - Арк.2.

19 Там само. - Спр.99. - Арк.1-3.

${ }_{20}$ Там само. - Спр.147. - Арк.1.

${ }_{21}$ Там само. - Спр.162. - Арк.1-2.

22 Там само. - Спр.174. - Арк.1-9.

${ }_{23}$ Там само. - Спр.181. - Арк.1-31; Спр.208. - Арк.1-11.

${ }^{24}$ Там само. - Спр.301. - Арк.1-2.
} 
of August 14, 179425. Simultaneously, the authorities asked the Greek community to choose a worthy person in their midst who could be ordained as a priest.

According to the lists of 1805 and 1808 , Grigoriy Radostat was the priest in the Church of St. Sophia. A member of a Greek merchant family, he was ordained to priesthood and sent to Kherson by Bishop Gervasius of Theodosius in 1797. In I805, he became the deacon of the Kherson district. The list of I808 stated that he 'behaved honestly, the deeds defaming his behaviour were not known about, and he was never fined ${ }^{26}$.

In 1808 , the parishioners of the Church were residents of 37 yards ( 148 men and I32 women) of the Greek merchant $\mathrm{class}^{27}$. Despite the small number of parishioners, the Kherson Greek Church was rebuilt and decorated several times. In 1798, a throne in honour of the great martyr Barbara was erected in a wooden Greek church ${ }^{28}$. In I8oI, an Imperial Decree prohibited building wooden churches because of a related fire in the Mosalsk district of Kaluga province ${ }^{29}$. In I802, the Kherson Greek Church of St. Sophia was redesigned as a basilica ${ }^{30}$. In 1808 , it was rebuilt using stone (shell rock was used). However, its wooden drum, lined with iron, is still extant.

In July I8II, the parishioners agreed to accept a former priest of the Odesa Greek Battalion Konstantin Sirigov to their church. He was likewise a scion of a Greek merchant family and began serving in Taganrog. Then, he served in the Odesa Greek Battalion for more than six years, and took part in the Russo-Turkish War of I807-I8I2. He was discharged from military clergy due to illness. Considering him a worthy man, most of the parishioners supported his candidature ${ }^{31}$. However, the following year he asked for another place because he could not provide for his family with a meagre income from a small parish $^{32}$. He was granted permission to search for another place in the diocese, but in I8I6 he was still serving in the Greek Church of St. Sophia ${ }^{33}$.

In I809, the elder of the Kherson Greek Church Matthew Zoro died, and in the summer of I8Io, the church community elected a new elder - the Greek merchant George Papafoma. At that time, there was another priest in the church - Mikhail Mantoev ${ }^{34}$. Later, he was replaced by Dmitry Stoyanov, a Bulgarian ${ }^{35}$. In I8I3, the elder of the church was re-elected: the parishioners voted in Odesa merchant Anastasiy Mikhailov ${ }^{36}$. In I8I5, a conflict broke out between Mikhailov and Stoyanov over church expenses ${ }^{37}$. It seems, at that time, the conflict had no consequences. However, in I829-I830, the parishioners of St. Sophia Church accused Archpriest Demetrius Karlich, a priest in the Greek Church since 1824 , of laziness, negligence, and misuse of church money. They sought to release him from church service. Conversely, he argued that he had spent a significant amount of his own savings on the church and wanted them returned. When considering this case, the Investigative Commission invited the priest of Mykolaiv Greek Church Nikolay Mazharov to submit evidence. He tried to avoid participating and pretended to be sick with bilious fever (he presented a certificate signed by Main Doctor of the Mykolaiv Naval Hospital

\footnotetext{
${ }_{25}$ Там само. - Спр.197. - Арк.1-4.

${ }_{26}$ Там само. - Спр.647. - Арк.8; Спр.760. - Арк.2.

27 Там само. - Спр.647. - Арк.8; Спр.760. - Арк.2.

${ }_{28}$ Пивовар А.В. До питання про церковне будівництво... - С.135.

29 ДАХО. - Ф.207. - Оп.1. - Спр.413. - Арк.1-2.

${ }^{30}$ Пивовар А.В. До питання про церковне будівництво... - С.145.

${ }^{31}$ ДАХО. - Ф.207. - Оп.1. - Спр.950. - Арк.1-8; Спр.977. - Арк.1-4.

32 Там само. - Спр.985. - Арк.1.

${ }_{33}$ Там само. - Спр.1195. - Арк.67-69.

${ }_{34}$ Там само. - Спр.915. - Арк.1-6.

35 Там само. - Спр.1032. - Арк.1-2.

${ }_{36}$ Там само. - Спр.1095. - Арк.4.

${ }_{37}$ Там само. - Спр.1154. - Арк.1-8.
} 
Petrushevsky). He also claimed that the absence of another Greek-speaking priest in Mykolaiv precluded him from leaving the city. The case reached Commander-in-Chief of the Black Sea Navy and Ports, Vice Admiral M.Yazykov. All transactions between Karlich and the architect, contractors, and suppliers were checked ${ }^{38}$. Unfortunately, the archival documents describing the end of this case have not been discovered yet.

S.Makarov argued that priest Serbinov made one additional architectural change in I838. Two thrones appeared in the renovated Greek Church of St. Sophia: the lower one in honour of the Nativity of Mother of Christ, the upper one - for St. Constantine and St. Helen ${ }^{39}$. The Greek Church of St. Sophia is rectangular and consists of three naves different in height. The naves are divided by columns in two rows. These ro columns are clearly visible on the plan of the Church. To the East, the space of the Church finishes in low apse, corresponding to the naves. To the West, the central entrance begins from a three-tiered bell tower. The architecture of the facades is quite restrained: the walls are topped with cornices and decorated with mosaics. Two rows of rectangular and semicircular windows and niches alternate. The interior is decorated with wall paintings and carvings. There is an intricately carved baldachin above the altar, depicting the Lord Almighty. The bell tower is adorned with sculptures of the four Evangelical Apostles. The belfry tiers are also decorated with cornices. The lower tiers of the bell tower are cubic, while the upper tiers are cylindrical.

It is possible that the Kherson Greek Church imitates the Church on the island of Chios as it appeared in the last quarter of the eighteenth century - the first quarter of the nineteenth century. Moreover, the Kherson Greek Church retains the original iconostasis and sculptures from the old Chios Church.

Moreover, the Greek settlers established the first market square and Greek street in Kherson where they erected homes, warehouses, and shops. After the death of Prince Grigory Potemkin in I79I, the 'porto-franco' in Kherson was cancelled. It made the climate for export-import trade unfavourable. In I794-1795, the Department of the Black Sea Navy and all naval institutions were transferred from Kherson to Mykolaiv. The Greeks serving in the Navy moved to Mykolaiv together with the Naval Department. Even though Kherson became the centre of the province in I803, the majority of civil Greeks abandoned it and moved to Odesa which was granted the 'porto-franco' by the Decree of the Russian Empire government of April 16, I8I7. Subsequently, Odesa became a global centre of trade and culture as well as the cradle of the Greek movement for Independence.

\section{Distinctive Features of Greek Church in Mykolaiv}

The story of stone Greek Church construction in Mykolaiv is worthy of a detective novel. Mykolaiv was founded in 1789 . On December 6, I788, Russian troops successfully captured the Turkish fortress Ochakiv (now town Ochakiv, 6o km from Mykolaiv). According to Christian tradition, St. Nicholas, the patron of sailors, is celebrated on December 6. When choosing the name for the new city which was to become the centre of shipbuilding on the Black Sea and the biggest military base of the Russian Imperial Navy, its founder Prince Grigory Potemkin decided to honour the Christian saint and named the city after the victory over the Ottomans in Ochakiv.

\footnotetext{
${ }^{38}$ Там само. - Спр.1745. - Арк.1-101.

39 Макаров С. Греки Херсона // Херсонский вестник. - 2012. - №9 (1123). - С.19.
} 
At the end of the eighteenth century, a rich Greek trading quarter - 'Greek rows' flourished in the very centre of Mykolaiv. After the Department of the Black Sea Navy (the Naval Department) was moved from Kherson to Mykolaiv, this city began to turn into a 'military marine citadel'. The foreign trade ships were not allowed to enter the Mykolaiv port. Local merchants could only earn money by contracting the Admiralty. Thus, the Greek merchant families moved to Odesa. In I805, Mykolaiv became the centre of the Mykolaiv and Sevastopol military governorship; Commander-in-Chief of the Black Sea Navy and Ports served as governor in both of these cities. During the nineteenth century, most of the Greeks serving in the Black Sea Navy were living in Mykolaiv. Two of them, Nikolay Arkas and Mikhail Manganary, were Commanders-in-Chief of the Black Sea Navy and Ports and governors.

The builder of the Mykolaiv city, Kriegskommissar Mikhail Faleev, requested a church construction permission from the Archbishop of Katerynoslav, Kherson and Tavria Ambrosius on December 19, I789: 'I made a promise to build a church in the name of Saint Nicholas'40. Based on this record, N.Kukhar-Onyshko argued that the Greek Church of St. Nicholas was built by Faleev in 1790 and the requiem service for Prince Grigory Potemkin was held in it ${ }^{4 \mathrm{I}}$.

The State Archives of Odesa region provided more reliable evidence: the wooden Greek Church in Mykolaiv was built in $1794^{42}$. The archives keep the first metric book of this church dated I799. No metrics from the earlier periods were saved. From January to November 1799, hieromonk Bartholomew, who was the priest in the Church at that time, baptized eleven new-borns and ran the memorial service for the wife of Mikhail Nazarov, a Greek. In the metric book for I8oI, Stephan Tomashevskiy is listed as the priest for October. Priest Athanasiy Langerov was mentioned in the church archival records dated April i804. Konstantin Marabut started ministering in the Mykolaiv Greek Church in 1807 . The parishioners mentioned in those metric books were recorded as 'foreign merchant - a Greek', among them Mikhail Nazarov, Nestor Aniatov, Paniot Mikhailov, Nikolay Kerdopulo, Ioan Samopulov, Ivan Ivanov, Nikolay Aleksandrov, Theodosiy Konstantinov, Ivan Philipov, Andrey Mikhailov, Ilya Ilyin, Adam Leontiev, Nestor Yegorov, Konstantin Pavlov, Mikhail Ternovet, Nikolay Grigoriev, and a Naval Fleet Lieutenant Mikhail Nikolaev. It is difficult to recognize the Greeks by these names. Obviously, after immigration, they either got Russian names and surnames or adapted the spelling to Russian linguistic sensibilities.

The wooden Greek Church of St. Nicholas eventually declined and became unfit for worship. On behalf of the Mykolaiv Greek community, on July I8, I799, a parishioner Spiridon Mikhailich asked Metropolitan of Katerynoslav and Tavria Gabriel (Bonulesco-Bodoni) for permission to build a new stone church and to launch a special book to record donations for temple construction. There are more than twenty signatures in Greek on the Greek version of the warrant issued by the Mykolaiv Greek community to Spiridon Mikhailich. Only ten of them were decoded. These names include Manolis Nikolu, Theodoros Cosa, Anastasiy Solidoru, Panayotis Lampadaru, Georgis Christodoru, Ioannis Georgiu, Dimitris Sanariotis, Nikolas Ioannis, Theodoros Kizani, and Michalis Siligu. It is these people who initiated the construction of the stone Greek Church in Mykolaiv. The permission was received on July 28, 1799, not only from the spiritual authorities but also from the Russian Emperor. Spiridon Mikhailich obtained a special book from the Novorossiysk Consistory to record voluntary donations for two

\footnotetext{
40 Российский государственный архив Военно-морского флота. - Ф.245. - Оп.1. - Д.33. - Л.818.

${ }^{4} 1$ Кухар-Онышко Н.А. Жизнь и смерть светлейшего князя Потёмкина... - С.89.

${ }^{42}$ ДАОО. - Ф.37. - Оп.4. - Спр.32. - Арк. б/н.
} 
years. The letter of the Consistory stated that the church construction could not be started until the corresponding fund would be accumulated ${ }^{43}$.

However, by I8os the construction had not yet begun. It is possible that the Greek community was not able to raise the required amount of money. On August 23, I805, the Mykolaiv Greek community again applied for permission to build a stone church. On February 23, I806, Mykolaiv military governor, Admiral Ivan de Traversey, on behalf of the Greek community ${ }^{44}$, urged Archbishop Athanasius to issue a new permission for the stone church building. It was granted on March 5, 1806, and according to the Katerynoslav Spiritual Consistory solution, Archpriest of the Admiralty Cathedral Evphimiy Savurskiy was to lay the first stone. The Decree of the Emperor was announced on March 22, 1806, in the presence of archpriests Grigoriy Sarazhinov and Karp Pavlovskiy and priest Grigoriy Radostat. To fulfil the Decree, Evphimiy Savurskiy laid the first stone of the Greek Church of St. Nicholas on April 25, 180645.

Despite their modest means, the Mykolaiv Greeks had raised 1576 rubles 63 copecks by April I806, and the church construction started. Evphimiy Savurskiy pointed out in one of his reports that the wooden Greek Church annually received no more than 200 rubles and spent this money on purchasing candles, oil, coal, and altar bread. However, while visiting the city, the wealthy Greeks who were Ottoman subjects contributed to the local Greek community development in every possible way. Therefore, the community succeeded in raising considerable funds within a short period - 8445 rubles 64 copecks. However, at the end of November 1806, the next Russo-Turkish War started and lasted until May I8I2. During this period, the Greeks did not have an opportunity to cross the borders freely, and assistance ceased. By mid-November I8I2, only the dome of the stone Greek Church in Mykolaiv had been completed ${ }^{46}$.

In I8o8, Archbishop of Katerynoslav, Kherson, and Tavria Platon granted a new special book from his Chancery to the priest of the Mykolaiv Greek Church Konstantin Marabut for recording the donations of parishioners and all those who wished to contribute to the church construction. The entries in this book were made in both Greek and Russian. Such surnames as Bakka, Raftopulo, Kalageorgii, Stiglitz, Pomerantzov, Knyaginskiy, Komarovskiy, Papafanasopulo, Melnikov, Arkas, Letnyakovskiy, Marabut, Albertev, Katenikov, and Kustov are listed in the book. The analysis of surnames makes it possible to conclude that people of different nationalities and religions donated money for the Greek Church construction. For example, Nikolay Stiglitz was a member of a prominent Jewish family ${ }^{47}$. On the behest of auditor Maxim Goncharov, on May I, I809, city police chief Nikolay Valshevich donated the icons of St. Nicholas and Virgin Hodegetria Smolenskaya to the Greek Church. Additionally, he contributed Ioso rubles according to the will of Archimandrite Zakhariy Petropulo ${ }^{48}$.

The figure of Zakhariy Petropulo, who is much revered in Ukraine, deserves particular consideration. There is no doubt that he could have served in the Greek Church in Mykolaiv, although his name is not listed in the extant metrical books. The inscription on his grave near the All Saints Church in the city cemetery states: 'In the city of Mykolaiv

\footnotetext{
${ }_{33}$ Там само. - Оп.1. - Спр.604. - Арк.1-5.

${ }^{44}$ It is difficult to determine the Greek population size in Mykolaiv in the first part of the nineteenth century because there are no statistical records about the population distribution by nationality. According to the Admiral de Traversey's report dated 1806, 114 foreigners lived in Mykolaiv. Military men were not included in the category of foreigner. The Mykolaiv Statistical Committee ran a local population census in 1875 and found that 119 citizens spoke Greek.

45 ДАОО. - Ф.37. - Оп.1. - Спр.710а. - Арк.1-2, 6.

${ }^{46}$ Там само. - Спр.767а. - Арк.8.

${ }^{47}$ Державний архів Миколаївської обл. - Ф.168. - Оп.1. - Спр.479. - Арк.1-21.

48 Там само. - Арк.11.
} 
on December 25, I808, the body of Archimandrite Zakhariy Petropulo, born on the island of 'Tinos in 1743 , was committed here to eternal peace'. Petropulo is said to be the Greek priest who saved Andreas Arkas from slavery at the Larisa market. He was a spiritual guide to the Arkases in Mykolaiv. Andreas graduated from the Litochoro Theological School. He married Assimina Haskaru. Their eldest son Zakhariy, born in Greece in I793, became a Rear-Admiral, a historian of the Black Sea Navy, and the founder and first director of the Sevastopol Maritime Library. Andreas participated in the national liberation struggle. His family was forced to flee the homeland. Knowing twelve languages, he became a translator for the Department of the Black Sea Navy and created a parallel dictionary of marine terminology ${ }^{49}$. In $\mathrm{I}^{807}$, the Arkases' daughter, Helen, was baptized in the wooden Mykolaiv Greek Church. In I8I8, another son, Nikolay, was born in Mykolaiv. He became a well-known statesman in the Russian Empire: an Admiral, Commander-inChief of the Black Sea Navy, and Mykolaiv military governor. The Arkases' national identity gradually evolved from a Greek one into Russian and then into Ukrainian. Nikolay Andreevich Arkas's son, Nikolay Nikolaevich, founded a local chapter of the Ukrainian Society 'Prosvita' in Mykolaiv and wrote a popular manual on the history of Ukraine. The family mausoleum of the Arkases is situated on the opposite side of Petropulo's grave.

The story of the Arkases clear demonstrates the evolution of the worldview of the Greeks who entered the Navy of the Russian Empire at the end of the eighteenth - at the beginning of the nineteenth century. The Orthodoxy equalized the Greeks in rights with representatives of other nationalities of the Orthodox denomination. Besides, the Greeks who served in the Black Sea Navy became an integral part of a special population group military seafarers. In Mykolaiv, there was no discrimination based on nationality, excluding the Jews. The inhabitants of the city differed by occupation: the 'military men' and 'civilians'. Mykolaiv differed from Odesa with its diversity and freethinking. Everything in Mykolaiv was connected with the Navy and the Admiralty. The historian Grigory Ge states that the civil society in Mykolaiv was pushed to the background and the naval atmosphere reigned everywhere. Not only the Greeks, but also representatives of other nations came under the influence of that atmosphere. Gradually, military men lost their national identity, and in the second and third generations they turned into loyal sons of the Russian fatherland'. The military seafarers and their families were parishioners of the Admiralty Cathedral of St. Grigory of Great Armenia. All their thoughts and deeds, including religious ones, were focused on the Fleet, and they were not interested in the civil life of the city. The civil Greeks raised money for church construction with such difficulty because their Church was in no way affiliated with the Naval Department and the Marines.

Since the raised money was still insufficient to complete construction, on July i8, I8I2, the Greek community asked Prince Alexander Golitsyn, who at that time was a member of the State Council of the Russian Empire and Head of the Theological Schools Commission, to grant them additional funds. Prince Golitsyn petitioned the Emperor to obtain 5000 rubles. The Decree was adopted on August 5, I8I2, but due to bureaucratic procedure, the Greeks had to wait almost three years to get the money. Finally, on June 16, I815, Metropolitan of Novgorod and St. Petersburg Ambrose (Podobedov) reported that the Theological Schools Commission sent the money to the Katerynoslav Treasury Chamber, and Hieromonk Ambrosiy, the treasurer, received this money. Archpriest Evphimiy Savurskiy informed the Mykolaiv Greek community that they had to send a

\footnotetext{
${ }^{49}$ Березовская Т.В. Аркас Андреас (Андрей) Эммануилович (1766-1825) [Electronic resource]: http://history.mk.ua/ andreas-andrej-e-mmanuilovich-arkas-1766.htm
} 
representative with a warrant to Katerynoslav to get this money. However, the Greek community behaved in a strange manner: its churchwarden Evstratiy Andrutsaki and trustees Paniot Manganary, Konstantin Aprat, and Andreas Arkas did not hurry to receive the money and asked to receive it by mail. The reason was that none of them could go to Katerynoslav because they were busy with their commercial activities. Eventually, the Treasury sent the money by mail. The Chamber instructed Savurskiy to withhold twenty-five rubles from the Greek community as insurance. Before the end of November, Savurskiy was forced to correspond with different institutions about these twenty-five rubles. On August 3I, I8I5, he received 5000 rubles and, on September 2, I8I5, handed them over to churchwarden Evstratiy Andrutsaki in the presence of priest Nikolay Mazharov and trustees Paniot Manganary, Theodosiy Konstantinov, and Major Yegor Albertov. Having supervised the money transfer process, the city police chief Nikolay Valshevich wrote a report and verified it with his signature and seal. However, on September 20, I8I5, the trustees of the Greek Church reported to Metropolitan Ambrose that the funds received were not sufficient to complete construction. They complained that the community was small, and construction materials were unreasonably expensive. They were in a hurry to cover the roof because winter was coming. Thus, they borrowed building materials. Having received the money, they distributed it to the lenders immediately. Consequently, they barely had enough money to complete exterior work. The trustees asked Ambrose for additional money 'for the interior completion of the Church building as much as Your Eminence could bless us with'. They wrote to the Metropolitan that if he provided them with additional funds, 'Your Holy name in front of the altar in the Church of God would be proclaimed before the Savior Christ in all the coming days of this temple's existence'. Metropolitan Ambrose instructed Savursky to inform the applicants that they were not to start such a large-scale construction, knowing the community's inability to raise the necessary funds. He clearly explained: 'I cannot take the trouble of this responsibility again'so. Nevertheless, the Church was completed and consecrated on January I8, $\mathrm{I} 8 \mathrm{I} 7^{5 \mathrm{I}}$. The source that donated additional money for Church construction is still not determined.

While the civil Greeks were seeking permission and money to build their Church, the Admiralty Cathedral of the Naval Department, the parishioners of which were the military Greeks, was in the process of construction. It took approximately four years from 1790 to 1794 . Unfortunately, the Cathedral was destroyed in 1936 under 'the Soviet plan for the reconstruction of the city's central square'. However, numerous images and architectural plans of the cathedral were preserved. It is believed that the project of the Admiralty Cathedral was based on St. Sophia's Temple in the Byzantine city of Adrianople (nowadays - Edirne, Turkey). The Admiralty Cathedral was built in the shape of an elongated cross. It was a pillarless cross-domed one-apse one-throne temple. This design was characteristic of Orthodox churches since Byzantine times. In general, the architectural design of the Admiralty Cathedral followed the style of laconic classicism. The temple was huge, accommodating up to seven hundred believers. The authorship of the Admiralty Cathedral architectural project belonged to Ivan Starov, a prominent architect of the late eighteenth - the early nineteenth centuries. The idea was realized by Antoine Vecton and Ivan Knyazev. In addition to Starov and Knyazev, architects Vincent Vanrezant, Karl Hagendorf, and Peter Neyelov participated in the Admiralty Cathedral project. In April 1792, Hagendorf and Neyelov expressed an opinion that the temple walls were not strong enough to support the weight of the brick-arched vault, the drum, and the dome. Then, Knyazev suggested

\footnotetext{
${ }_{50}$ ДАОО. - Ф.37. - Оп.1. - Спр.767а. - Арк.1-31.

${ }_{51}$ Там само. - Оп.4. - Спр.58. - Арк.29.
} 
building a wooden ceiling instead of a heavy brick-arched vault. Additionally, he wanted to arrange four arches at the intersection of naves to support the drum and the dome. His proposals were accepted and later proved to be correct $^{t^{2}}$.

The construction process of the Admiralty Cathedral is important to understanding the way in which St. Nicholas Greek Church could have been designed. The original project, the names of architects and builders of the Church have not been discovered in the archives yet. Comparing the project and the images of the Admiralty Cathedral to the existing Greek Church building, one might suggest that the Greek Church is a smaller copy of the Admiralty Cathedral. The Church was built in the same style of strict classicism. This similarity is not surprising: in the naval city, where the vast majority of Greeks served in the Navy, the Greek Church can be erected only as a copy of the most important spiritual building for seafarers - the Admiralty Cathedral. The architects of the Church had to be the same people who had previously developed the project of the Cathedral. However, the Greek Church has its own design peculiarities. For example, the weight of the drum and dome that had been discovered to be an issue during the Admiralty Cathedral construction was now noted. The walls of the Greek Church were more massive, which allowed the arched ceiling to be erected. Inside of the Church, the builders installed eight pillars (columns) paired together. The drum and the dome are supported by these pillars. For this reason, the Church is an eight-pillars cross-domed temple. Most temples have had only four pillars, which is why the Greek Church in Mykolaiv is unique in architectural design.

Similar to the Admiralty Cathedral, two-tier windows were arranged on the side walls in the Greek Church. The semi-circular windows on the drum provided the interior space of the temple with sufficient illumination. The single-tier iconostasis is quite simple in design. The Greek Church has a two-tier bell tower erected above the entrance to the temple as was done in the Admiralty Cathedral. The Greek Church is a one-nave, one-apse, one-throne temple. The Admiralty Cathedral was lost forever, but the Greek Church is preserved in its original form, which sheds light on the architecture of Mykolaiv in the nineteenth century.

When Nikolay Mazharov became a priest in the Mykolaiv Greek Church, it was consecrated at last. Mazharov was born in the Greek colony Malyi Buyalyk and originated from a Greek noble family. He moved to Odesa in 1802 and was ordained as a priest by Archbishop Platon in I808. At first, Mazharov was a deacon at St. John the Baptist Church in Malyi Buyalyk. In I8I2, he became a priest of the Church of the Dormition of the Mother of God in Old Crimea. On March 8, I8I5, according to the Decree of the Consistory, Nikolay Mazharov was assigned to Mykolaiv. On April 8, I818, he received a bronze cross on the Vladimir ribbon in commemoration of the Russian Empire victory in the War of I8I2. He served as the priest of the Greek Church for almost thirty years ${ }^{53}$.

The Greeks had the most influence on the Black Sea Navy development when Admiral Aleksey Greig (I816-1833) was the military governor and Commander-in-Chief of the Black Sea Navy and Ports. After taking office, his opponent Admiral Mikhail Lazarev (I833-185I) expelled all foreigners, including the Greeks, from Mykolaiv and Sevastopol. This decision had a negative impact not only on the Black Sea Navy but also on the situation in these cities in general. After Lazarev's death, the Greeks returned to their positions $^{54}$. The names of the prominent Greek seafarers who served in the Black Sea Navy are mostly recorded in the metric and confession books of the Admiralty Cathedral. Among them are Vice-Admiral Anton Alexiano, Admiral Michail Manganary, Hydrograph Yegor

\footnotetext{
52 Щукин В.В. Николаевский Адмиралтейский собор: Очерк истории. - Николаев, 2017. - С.6-22.

53 ДАОО. - Ф.37. - Оп.4. - Спр.58. - Арк.32.

${ }_{54}$ Левченко Л. Історія Миколаївського і Севастопольського військового губернаторства (1805-1900). - Миколаїв, 2006. - C.179-202.
} 
Manganary, Fleet General Ivan Manganary, Vice-Admiral Konstantin Patanioty, RearAdmiral Nikolay Patanioty, Rear-Admiral Nikolay Kumany, Admiral Michail Kumany, Fleet General and Hydrograph Nikolay Kumany Jr., and representatives of the Arkases. The names of their relatives and descendants who did not serve in the Navy can be found in the metric books of the Greek Church of St. Nicholas.

In I862, due to the efforts of Commander-in-Chief of the Black Sea Navy and Mykolaiv military governor Bogdan von Glazenap, the Mykolaiv port opened to international trade. Greek merchants contributed significantly to grain export. For example, Panteleimon Zigomalas, a Greek, founded a grain export office in Mykolaiv in I864. During the second half of the nineteenth century, twenty foreign consulates were opened in Mykolaiv, including the Consulate of the Kingdom of Greece in 1876. Georgiy Zigomalas, son of Panteleimon, was appointed as a Greek consul. It was he who recreated and reinforced the relations of the Mykolaiv Greeks with Greece. After the death of Georgiy Zigomalas, the consular duties were taken over by his brother, Ivan. He continued to maintain relations with both the King of Greece George the First and Prime Minister Eleftherios Venizelos. In the late nineteenth -early twentieth centuries, thousands of Pontic Greeks moved to the South of Russian Empire to escape persecution in the Ottoman Empire. They established a Greek colony in Mykolaiv. The Greek Church of St. Nicholas and the Greek Consulate became centres that united Pontic Greeks. In 1919, Venizelos signed an agreement with the Entente to send a military contingent to Ukraine to fight the Bolsheviks. The Seventh Athens Infantry Regiment was deployed to Mykolaiv. On March 9, I9I9, all members of the Mykolaiv Greek colony attended a prayer service in the Greek Church in honor of this Regiment anniversary5s. In 1929, when the persecution of churches started, the Mykolaiv Greeks, as a part of the Council of the St. Nicholas Greek Church, began to fight against the closure of the Church. The Greek Church was closed in 1939, but as early as 194I, worship started again and is still ongoing.

The history of Greek churches reflects the history of the Greeks in the South of Ukraine under the dominion of the Russian Empire. When the Greeks settled in Kherson, their ties with their country of origin were quite strong. It is clear in the decor of St. Sophia's Greek Church and in the wishes of the community to have the priests help services in Greek. The Russian government tended to control Greek citizens with the help of the Russian Orthodox Church. Greek priests obeyed the regulations of the Russian Church. By the time the Greeks reached Mykolaiv, their ties with their native land had become weaker. The Greeks serving in the Black Sea Navy were hardly interested in the St. Nicholas Greek Church construction because the Admiralty Cathedral satisfied their religious needs. These Greeks were subjected to assimilation faster than their compatriots who did not serve in the Navy. The Mykolaiv community of civil Greeks was insolvent and could not build their Church without government aid and the donations of benefactors of other nationalities. The lack of funds instigated a search for money, disputes on financial issues, and mutual recriminations of fraud. The assimilation of civil Greeks manifested in the architecture of Mykolaiv Greek Church, built as a smaller copy of the Admiralty Cathedral, in the Russian names of Greek parishioners, and in the control that the Russian priests had over the church. The history of Kherson and Mykolaiv Greek churches is different from the history of Odesa Holy Trinity Church that became a shelter for participants of the movement for Greek statehood. The Greek churches not only helped the Greeks integrate into a foreign environment and preserve their national culture but also promoted their assimilation.

55 Левченко Л. Українська кампанія грецької армії 1919 р.: вплив на подальшу долю українських греків (на прикладі Миколаєва й Миколаївщини) // Сторінки історії. - 2019. - №4. - С.59-91. 


\title{
REFERENCES
}

1. Petlyuchenko V., prot. (2002). Svyato-Troitskaya Grecheskaya Tserkov v Odesse (1808-2001 gg.). Odessa. [in Russian].

2. Pyvovar, A.V. (2018). Do pytannia pro tserkovne budivnytstvo na terytorii kraiu v druhii polovyni XVIII - pershii tretyni XIX st. (Khersonshchyna i pravoberezhna Katerynoslavshchyna). Inbulskyi step: istoriia, kraieznavstvo, rodovid, dzherela, spadshchyna, 3, 103-169. Kyiv. [in Ukrainian].

3. Shchukin, V.V. (2017). Nikolaevskiy Admiralteyskiy sobor: Ocherk istorii. Nikolaev. [in Russian].

4. Terentieva, N.O. (2005). Taiemne hretske tovarystvo "Filiki Eteriia": Orbanizatsiinyi ta polityko-ideolobichnyi tsentr pidhotovky bretskoi revoliutsii 1821-1829 rr. Kyiv. [in Ukrainian].

5. Terentieva, N.O. (2008). Hreky v Ukraini: istoriia ta suchasnist. Kyiv. [in Ukrainian].

6. Timofeenko, V. (1984). Goroda Severnogo Prichernomorya vo vtoroy polovine XVIII v. Kiev. [in Russian].

7. Tomozov, V.V. (2020). Hreky-khiostsi na Pivdni Ukrainy (kinets XVIII st. - 1917 r.): mizh tradytsiiamy natsionalnoho samozberezhennia i praktykamy sotsiokulturnoi adaptatsii. Kyiv. [in Ukrainian].

\author{
Лариса ЛЕВЧЕНКО \\ докторка історичних наук, професорка, \\ старша наукова співробітниця, \\ Інститут української археографії та джерелознавства \\ ім. М.С.Грушевського НАН України; \\ директорка Центрального державного архіву \\ вищих органів влади та управління України \\ (Київ, Україна), loralewch@gmail.com \\ ORCID: https://orcid.org/oooo-oooI-9097-7373
}

\section{Становлення грецьких церков у Південній Україні (кінець XVIII - перша половина XIX ст.)}

Анотація. Метою статті є репрезентація результатів дослідження історії херсонських та миколаївських грецьких церков наприкінці XVIII - у першій половині XIX ст. Методологія дослідження базується на загальноприйнятих принципах і методах історичної науки. Наукова новизна. Історія грецьких церков Херсона та Миколаєва висвітлюється на основі рукописних джерел із державних архівів Херсонської, Миколаївської, Одеської обл., які вперше вводяться в науковий обіг. Це дало можливість вивчити нові факти та імена, зробити висновки про роль церкви у житті херсонської й миколаївської грецьких громад. Висновки. Історія грецьких церков відображає історію греків на півдні України під владою Російської імперії. Коли греки оселилися у Херсоні, їхні зв'язки з Батьківщиною були ще досить міцними. Це видно в декорі Софійської грецької церкви, у бажанні мати грекомовних священиків. Російський уряд намагався взяти під контроль грецьких громадян за допомогою православної церкви. Грецькі священики мали підкорятися уставам російської церкви. На той час, коли греки дійшли до Миколаєва, їхні зв'язки з рідною землею ослабли. Греки, які служили на Чорноморському флоті, майже не цікавилися будівництвом грецької церкви Св. Миколая, оскільки Адміралтейський собор задовольняв їхні релігійні потреби. Ці греки піддалися асиміляції швидше, ніж їхні співвітчизники, котрі не служили на флоті. Миколаївська громада цивільних греків була неспроможна будувати свою церкву без державної допомоги та пожертвувань представників інших національностей. Нестача бюджету викликала пошуки коштів, суперечки з грошових питань, взаємні звинувачення у шахрайстві. Асиміляція цивільних греків відбилася в архітектурі Миколаївської грецької церкви, збудованої як зменшена копія Адміралтейського собору, у зросійщених іменах греків, які були парафіянами грецької церкви, і в контролі, який мали над нею російські священики. Історія херсонської та миколаївської грецьких церков відрізняється від історії одеської Свято-Троїцької церкви, яка стала притулком для учасників руху за національну державність. Грецькі церкви не тільки допомагали грекам інтегруватися у чуже середовище і зберігати національну культуру, але й сприяли їх асиміляції.

Ключові слова: грецькі церкви в Південній Україні, церква Св. Софії у Херсоні, церква Св. Миколая в Миколаєві, греки в Україні, греки на Півдні Російської імперії. 